\title{
HUBUNGAN TINGKAT KEMATANGAN DAN SUHU DENGAN SISA MAKANAN LAUK NABATI PADA PASIEN ANAK DI RUANG INAP RUMKITAL DR. RAMELAN SURABAYA
}

\author{
Correlation between Cooked Level and Temperatures with Plate Waste of Vegetable Side Dish \\ among Pediatric Patients at Naval Hospital Dr. Ramelan Surabaya \\ Renata Saskia $^{\text {* }}$, Suzanna Primadona ${ }^{2}$, Trias Mahmudiono ${ }^{1}$ \\ ${ }^{1}$ Departemen Gizi Kesehatan, Fakultas Kesehatan Masyarakat, Universitas Airlangga, Surabaya \\ ${ }^{2}$ Sub Departemen Gizi, RUMKITAL Dr. Ramelan, Surabaya \\ E-mail: renatasaskia30@gmail.com
}

\begin{abstract}
ABSTRAK
Evaluasi makanan suatu pelayanan gizi di rumah sakit dapat dilihat dari sisa makanan pasien. Kejadian sisa makanan dapat dipengaruhi oleh persepsi pasien terhadap makanan yang disajikan, seperti penampilan dan cita rasa. Penelitian ini bertujuan menganalisis hubungan tingkat kematangan dan suhu dengan sisa makanan lauk nabati pada pasien anak di Ruang Inap Rumah sakit TNI AL Dr. Ramelan Surabaya. Penelitian ini menggunakan desain cross sectional. Sampel penelitian merupakan pasien anak di ruang rawat inap sebanyak 32 orang. Pengumpulan data dilakukan dengan wawancara langsung terkait penilaian tingkat kematangan dan suhu makanan, serta observasi langsung pada sisa makanan pasien menggunakan metode taksiran visual Comstock. Uji statistik menggunakan chi-square. Hasil penelitian menunjukkan adanya hubungan yang kuat antara tingkat kematangan dan suhu makanan dengan sisa makanan lauk nabati yang disajikan malam hari $(\mathrm{p}=0,049$ dan $\mathrm{p}=0,040)$, namun tidak terdapat hubungan pada tingkat kematangan dan suhu lauk nabati pada siang hari $(\mathrm{p}=0,994$ dan $\mathrm{p}=0,505)$ serta hubungan lemah juga ditunjukkan pada rasa, aroma dan besar porsi lauk nabati dengan sisa makanan pasien dikarenakan adanya perbedaan selera makan, kebiasaan makan dan kondisi fisiologis pasien.
\end{abstract}

Kata kunci: pasien, sisa makanan, tingkat kematangan dan suhu makanan lauk nabati

\section{ABSTRACT}

Food evaluation in a hospital can be seen from patient's plate waste. Plate waste can be influenced by patient's perception of the food served, such as appearance and taste. The aim of this study was to analyze the relationship of cooked level and temperature of vegetable side dishes with plate waste in the pediatric patient at naval hospital Dr. Ramelan Surabaya. The study was using cross sectional design. The sample of the study was thirty-two pediatric patient. The data collected through interview using a questionnaire and plate waste was observed by Comstock method. Chi-square was used to analyzed the correlation of cooked level and temperature of vegetable side dishes with plate waste. The results showed that there was a relationship between cooked level, the temperature of the vegetable side dish and plate waste which served on dinner time $(p=0.049$ and $p=0.040)$, but there was no relationship between cooked level, the temperature of vegetable side dish and plate waste on lunch time $(p=0.994$ and $p=0.505)$. There was a weak relationship between taste, aroma, portion with the patient's plate waste, due to the different appetite, eating habits and physiological conditions of the patients.

Keywords: patients, plate waste, cooked level and temperatures of vegetable side dish

\section{PENDAHULUAN}

Pelayanan gizi di ruang rawat inap merupakan salah satu bagian penting dari perawatan pasien. Asuhan gizi (nutritional care) berperan penting dalam kesembuhan pasien selain melalui asuhan medis (medical care), dan asuhan keperawatan (nursing care). Kombinasi penanganan antar profesi di ruang rawat inap diperlukan untuk dapat 
menjamin terselenggaranya asuhan gizi secara adekuat (Prawirohartono, 2009). Asuhan gizi yang baik dapat mencegah seorang pasien menderita malnutrisi di rumah sakit selama dalam perawatan (Depkes, 2007).

Studi di Indonesia yang dilakukan pada beberapa rumah sakit Jakarta menunjukkan sebanyak $20-60 \%$ pasien malnutrisi dan $69 \%$ mengalami penurunan status gizi selama rawat inap di rumah sakit (Ayudhia et al., 2016). Kejadian malnutrisi yang terjadi pada anak seringkali ditemui di Rumah Sakit. Studi Koen dan Jessie (2008) di Rumah Sakit Rotterdam menunjukkan sebanyak $6,1-40,9 \%$ pasien anak-anak mengalami malnutrisi saat masuk Rumah Sakit.

Malnutrisi dapat disebabkan oleh kurangnya asupan zat gizi, penyakit infeksi dan gabungan dari berbagai faktor yang saling memengaruhi secara kompleks. Faktor yang memengaruhi antara lain, penyerapan makanan yang buruk, kehilangan zat gizi yang berlebihan atau gabungan dari faktor-faktor tersebut. (Barker et al., 2011).

Asupan makan pasien di rumah sakit tergantung pada tingkat kenyamanan pasien dalam mendapatkan makanan, mulai dari bentuk makanan, penyajian makanan, variasi makanan dan penampilan makanan. Penyajian makanan dengan pengaturan suhu pada waktu penyajian memegang peran penting dalam menentukan cita rasa makanan. Penyelenggaraan makanan dengan skala besar, memerlukan ketelitian dalam pendistribusian makanan terutama suhu makanan, seperti suhu pada nasi, lauk hewani dan lauk nabati. Konsumen cenderung kurang memiliki selera makan bila mengonsumsi makanan dengan suhu rendah atau tidak hangat (Atmanegara et al., 2013).

Suhu dapat menunjukkan suatu keadaan panas atau dingin. Hidangan makanan dalam keadaan panas dapat menimbulkan aroma yang mampu menjadi daya tarik makanan untuk dikonsumsi (Widyastuti dan Pramono, 2014). Tingkat kematangan juga menentukan suatu cita rasa makanan. Matang bila dinyatakan telah layak dikonsumsi, namun di Indonesia tingkat kematangan dimaksudkan harus dimasak sampai benar-benar matang (Widyastuti dan Pramono, 2014).
Analisis asupan gizi pasien terhadap makanan yang disajikan dapat dilihat dari evaluasi sisa makanan (Barker et al., 2011). Penelitian yang dilakukan Wahyunani et al. (2017) di RS Panti Rapih Yogyakarta menunjukkan masih banyak sisa makanan pasien, seperti nasi sebesar 35,62\%, lauk hewani $28,84 \%$, lauk nabati $33,75 \%$, sayuran $31,87 \%$ dan buah sebesar $10,61 \%$. Penelitian yang dilakukan di RSK Dr Tadjuddin Chalid dan RSUD Kota Makasar oleh Mas'ud et al. (2015) menunjukkan persentase sisa makanan pada makan siang dengan menu nasi sebesar $13,8 \%$, lauk hewani sebesar $15,9 \%$, lauk nabati sebesar $14,7 \%$ dan sayur sebesar 10,2\%.

Sisa makanan merupakan salah satu hal penting yang perlu diperhatikan di suatu rumah sakit. Malnutrisi pada pasien erat kaitannya dengan kejadian sisa makanan di rumah sakit, jika hal tersebut dalam jangka panjang tidak diperhatikan akan berdampak pada status gizi pasien yang semakin menurun (Depkes, 2007). Pada pasien rawat inap RS Prof. Dr. R.D. Karidou Manado sisa makanan lauk nabati dan lauk hewani masih tergolong banyak yaitu lebih dari $80 \%$. Oleh karena itu, asupan energi pasien hanya didominasi oleh asupan lemak dan karbohidrat, sedangkan sumbangan energi dari protein tergolong masih rendah karena pemenuhan protein kurang dari $80 \%$ (Lieke, 2013).

Berdasarkan data diatas, penulis tertarik untuk menganalisis hubungan tingkat kematangan dan suhu dengan sisa makanan lauk nabati pada pasien anak di rumah sakit, dengan menitikberatkan pada jenis makanan lauk nabati karena merupakan salah satu penyumbang asupan protein pasien. Penelitian dilakukan di Ruang Inap anak Rumah sakit TNI AL Dr. Ramelan Surabaya karena belum pernah ada penelitian ataupun pembahasan mengenai hal terkait.

\section{METODE}

Penelitian ini menggunakan desain cross sectional untuk menganalisis hubungan tingkat kematangan dan suhu makanan dengan sisa makanan pasien anak di ruang rawat inap RUMKITAL Dr. Ramelan, Surabaya, Jawa Timur yang dilaksanakan pada bulan 
Nopember-Desember 2017. Populasi penelitian ini adalah seluruh pasien anak yang dirawat di ruang rawat inap anak RUMKITAL Dr. Ramelan dengan sampel penelitian sebesar 32 pasien.

Sampel diambil dengan menggunakan metode purposive sampling dengan kriteria inklusi yaitu telah dirawat minimal satu hari di ruang rawat inap anak termasuk dalam kelas II dan III dan anak berusia 2-12 tahun. Pengumpulan data dilakukan dengan wawancara langsung kepada orang tua pasien untuk mengisi kuesioner penilaian persepsi tingkat kematangan dan suhu makanan sehingga mengetahui daya terima pasien.

Pencatatan data sekunder berupa nama, usia, jenis kelamin, pekerjaan orang tua, dan bentuk diet diperoleh dari rekam medis pasien. Observasi langsung pada sisa makanan pasien dilakukan menggunakan metode taksiran visual atau comstock. Metode comstock dipilih karena efisiensi waktu dan mudah diterapkan dalam penelitian. Presentase cut off, antara lain skor 0 (0\%) menandakan semua makanan dihabiskan, skor $1(25 \%)$ bahwa $75 \%$ makanan dihabiskan, skor $2(50 \%)$ bila separuh makanan dihabiskan $(50 \%)$, skor $3(75 \%)$ menunjukkan hanya $25 \%$ makanan dihabiskan, skor 4 (95\%) menunjukkan $5 \%$ makanan dihabiskan dan skor $5(100 \%)$ bahwa makanan utuh.

Analisis data bivariat menggunakan uji statistik chi-square dengan nilai signifikasi $\mathrm{p}<\alpha$ $(0,05)$. Penelitian dilakukan pada makan siang dan makan malam pasien, dikarenakan pasien tidak mendapatkan menu lauk nabati ketika makan pagi, sehingga pengambilan data dilakukan sebanyak dua kali sehari pada tiap responden.

\section{HASIL DAN PEMBAHASAN}

\section{Karakteristik Responden}

Karakteristik pasien yang diteliti meliputi usia, jenis kelamin, pekerjaan orang tua dan bentuk diet yang terima oleh pasien anak di Rumkital Dr. Ramelan. Tabel 1 menunjukkan bahwa responden mayoritas berjenis kelamin laki-laki $(68,7 \%)$, usia balita $0-5$ tahun $(62,5 \%)$ dan sebagian responden belum sekolah $(40,6 \%)$.

Penelitian ini melibatkan peran keluarga/orang tua dalam memberikan penilaian terhadap cita rasa
Tabel 1. Distribusi Karakteristik Responden Pasien Anak Kelas 2 dan 3 di RS Rumkital Dr. Ramelan Surabaya tahun 2017

\begin{tabular}{|c|c|c|}
\hline \multirow{2}{*}{ Karakteristik Responden } & \multicolumn{2}{|c|}{ Jumlah } \\
\hline & $\mathbf{n}$ & (\%) \\
\hline \multicolumn{3}{|l|}{ Jenis Kelamin } \\
\hline Laki-laki & 22 & 68,7 \\
\hline Perempuan & 10 & 31,1 \\
\hline \multicolumn{3}{|l|}{ Pendidikan } \\
\hline Belum sekolah & 13 & 40,6 \\
\hline $\mathrm{TK}$ & 9 & 28,1 \\
\hline $\mathrm{SD}$ & 10 & 31,2 \\
\hline \multicolumn{3}{|l|}{ Kelompok Usia } \\
\hline $0-5$ tahun & 20 & 62,5 \\
\hline 5-11 tahun & 11 & 34,4 \\
\hline $12-16$ tahun & 1 & 3,1 \\
\hline \multicolumn{3}{|l|}{ Pekerjaan Orang Tua } \\
\hline Ibu Rumah Tangga & 2 & 6,2 \\
\hline Pegawai Swasta & 10 & 31,2 \\
\hline PNS & 1 & 3,1 \\
\hline TNI AL & 13 & 40,6 \\
\hline Wiraswasta & 6 & 18,7 \\
\hline \multicolumn{3}{|l|}{ Bentuk Diet } \\
\hline Nasi Biasa & 12 & 38,7 \\
\hline Nasi Tim & 18 & 25,8 \\
\hline Nasi Tim Lauk Cacah & 11 & 35,8 \\
\hline Nasi Tim Saring & 1 & 3,1 \\
\hline \multicolumn{3}{|l|}{ Jenis Penyakit } \\
\hline Saluran Cerna & 14 & 43,7 \\
\hline Saluran Pernafasan & 10 & 31,3 \\
\hline Pembuluh Darah & 5 & 15,6 \\
\hline Kanker/kemoterapi & 3 & 9,4 \\
\hline
\end{tabular}

makanan. Pekerjaan orang tua responden hampir sebagian besar merupakan TNI AL (40,6\%). Distribusi bentuk diet pada makanan pasien antara lain, diet nasi biasa sebesar $(38,7 \%)$, nasi tim $(25,8 \%)$ dan nasi tim lauk cacah $(35,8 \%)$. Jenis penyakit yang dialami oleh pasien sebagian besar penyakit saluran cerna sebanyak 14 orang $(43,7 \%)$ dengan beberapa diagnosa medis antara lain, tifoid, diare, mual, muntah, dehidrasi sedang dan usus buntu. Saluran pernafasan juga menjadi penyakit yang sering dialami oleh pasien anak $(31,3 \%)$

Tabel 2. Rata-Rata Sisa Makanan Lauk Nabati berdasarkan Waktu Makan

\begin{tabular}{lc}
\hline \multicolumn{1}{c}{ Waktu Makan } & Sisa Lauk Nabati (\%) \\
\hline Makan Siang & 56,3 \\
Makan Malam & 70,8 \\
Rata-rata & 63,5 \\
\hline
\end{tabular}


di Rumkital Dr. Ramelan, seperti batuk, pilek, tonsilitis, pneumonia dan asma.

Tabel 2 menunjukkan rata-rata sisa lauk nabati mencapai $63,5 \%$ dengan presentase sisa tertinggi pada makan malam sebesar 70,8\%. Menurut KMK no. 129/Menkes/SK/II/2008 tentang Standar Pelayanan Minimal Rumah Sakit, sisa makanan pasien dikatakan baik bila $\leq 20 \%$, sehingga dapat dilihat sisa makanan lauk nabati tergolong banyak dan belum mencapai standar minimum pelayanan Rumah Sakit. Hal ini menggambarkan bahwa pasien tidak mampu menghabiskan lauk nabati yang disajikan oleh Rumah Sakit karena masih banyaknya sisa lauk nabati. Penyebab tingginya sisa makanan tersebut dapat dikarenakan variasi olahan menu yang terbatas dan sederhana, sehingga pasien tidak suka terhadap lauk nabati yang disajikan, serta waktu penyajian yang kurang

Tabel 3. Hubungan Faktor Eksternal Rasa Makanan dengan Sisa lauk Nabati Pasien Anak Kelas 2 dan kelas 3 di RS Rumkital Dr. Ramelan Surabaya tahun 2017

\begin{tabular}{|c|c|c|c|c|c|c|c|c|c|c|c|c|c|}
\hline \multirow{3}{*}{ Variabel } & \multicolumn{12}{|c|}{ Sisa Lauk Nabati (\%) } & \multirow{3}{*}{ p-value } \\
\hline & \multicolumn{2}{|c|}{$\mathbf{0}$} & \multicolumn{2}{|c|}{1} & \multicolumn{2}{|c|}{2} & \multicolumn{2}{|c|}{3} & \multicolumn{2}{|c|}{4} & \multicolumn{2}{|r|}{5} & \\
\hline & $\mathrm{n}$ & $\%$ & $\mathrm{n}$ & $\%$ & $\mathbf{n}$ & $\%$ & $\mathrm{n}$ & $\%$ & $\mathrm{n}$ & $\%$ & $\mathrm{n}$ & $\%$ & \\
\hline \multicolumn{14}{|c|}{ Tingkat Kematangan Makan Siang } \\
\hline Kurang Sesuai & 0 & 0 & 0 & 0 & 0 & 0 & 0 & 0 & 0 & 0 & 1 & 3,1 & \multirow{3}{*}{0,994} \\
\hline Sesuai & 3 & 9,4 & 3 & 9,4 & 4 & 12,5 & 1 & 3,1 & 3 & 9,4 & 4 & 12,5 & \\
\hline Sangat Sesuai & 3 & 9,4 & 1 & 3,1 & 3 & 9,4 & 0 & 0 & 3 & 9,4 & 3 & 9,4 & \\
\hline \multicolumn{14}{|c|}{ Tingkat Kematangan Makan Malam } \\
\hline Kurang Sesuai & 0 & 0 & 0 & 0 & 0 & 0 & 0 & 0 & 1 & 3,1 & 0 & 0 & \multirow{3}{*}{$0,049^{*}$} \\
\hline Sesuai & 0 & 0 & 0 & 0 & 3 & 9,4 & 1 & 3,1 & 3 & 9,4 & 7 & 21,9 & \\
\hline Sangat Sesuai & 3 & 9,4 & 3 & 9,4 & 1 & 3,1 & 4 & 12,5 & 3 & 9,4 & 2 & 6,2 & \\
\hline \multicolumn{14}{|c|}{ Suhu Makanan Makan Siang } \\
\hline Kurang Hangat & 0 & 0 & 0 & 0 & 0 & 0 & 1 & 3,1 & 1 & 3,1 & 1 & 3,1 & \multirow{3}{*}{0,505} \\
\hline Hangat & 2 & 6,2 & 2 & 6,2 & 4 & 12,5 & 0 & 0 & 1 & 3,1 & 4 & 12,5 & \\
\hline Sangat Hangat & 4 & 12,5 & 2 & 6,2 & 3 & 9,4 & 0 & 0 & 4 & 12,5 & 3 & 9,4 & \\
\hline \multicolumn{14}{|c|}{ Suhu Makanan Makan Malam } \\
\hline Kurang Hangat & 0 & 0 & 0 & 0 & 1 & 3,1 & 1 & 3,1 & 1 & 3,1 & 1 & 3,1 & \multirow{3}{*}{$0,040^{*}$} \\
\hline Hangat & 0 & 0 & 0 & 0 & 2 & 6,2 & 1 & 3,1 & 1 & 3,1 & 7 & 21,9 & \\
\hline Sangat Hangat & 3 & 9,4 & 3 & 9,4 & 1 & 3,1 & 3 & 9,4 & 5 & 15,6 & 1 & 3,1 & \\
\hline \multicolumn{14}{|c|}{ Aroma Makanan Siang } \\
\hline Kurang Harum & 0 & 0 & 0 & 0 & 0 & 0 & 0 & 0 & 0 & 0 & 1 & 3,1 & \multirow{3}{*}{0,994} \\
\hline Harum & 3 & 9,4 & 2 & 6,2 & 3 & 9,4 & 1 & 3,1 & 4 & 12,5 & 4 & 12,5 & \\
\hline Sangat Harum & 3 & 9,4 & 2 & 6,2 & 4 & 12,5 & 0 & 0 & 2 & 6,2 & 3 & 9,3 & \\
\hline \multicolumn{14}{|c|}{ Aroma Makanan Malam } \\
\hline Kurang Harum & 0 & 0 & 1 & 3,1 & 0 & 0 & 1 & 3,1 & 0 & 0 & 1 & 3,1 & \multirow{3}{*}{0,544} \\
\hline Harum & 1 & 3,1 & 0 & 0 & 3 & 9,4 & 2 & 6,2 & 3 & 9,4 & 6 & 18,7 & \\
\hline Sangat Harum & 2 & 6,2 & 2 & 6,2 & 1 & 3,1 & 2 & 6,2 & 4 & 12,5 & 2 & 6,2 & \\
\hline Rasa Makanan Sian & & & & & & & & & & & & & \\
\hline Kurang Enak & 0 & 0 & 0 & 0 & 0 & 0 & 0 & 0 & 1 & 3,1 & 1 & 3,1 & 0.973 \\
\hline Enak & 3 & 9,4 & 3 & 9,4 & 4 & 12,5 & 1 & 3,1 & 2 & 6,2 & 4 & 12,5 & $0,9 / 3$ \\
\hline Sangat Enak & 3 & 9,4 & 1 & 3,1 & 3 & 9,4 & 0 & 0 & 3 & 9,4 & 3 & 9,4 & \\
\hline Rasa Makanan Mala & & & & & & & & & & & & & \\
\hline Kurang Enak & 0 & 0 & 1 & 3,1 & 0 & 0 & 0 & 0 & 1 & 3,1 & 2 & 6,2 & \\
\hline Enak & 0 & 0 & 1 & 3,1 & 3 & 9,4 & 2 & 6,2 & 3 & 9,4 & 5 & 15,6 & $0,5 / 1$ \\
\hline Sangat Enak & 3 & 9,4 & 1 & 3,1 & 1 & 3,1 & 3 & 9,4 & 3 & 9,4 & 2 & 6,2 & \\
\hline Besar Porsi Makana & & & & & & & & & & & & & \\
\hline Kurang Sesuai & 0 & 0 & 0 & 0 & 0 & 0 & 0 & 0 & 1 & 3,1 & 0 & 0 & \\
\hline Sesuai & 3 & 9,4 & 2 & 6,2 & 6 & 18,7 & 0 & 0 & 3 & 9,4 & 5 & 15,6 & 0,603 \\
\hline Sangat Sesuai & 3 & 9,4 & 2 & 6,2 & 1 & 3,1 & 1 & 3,1 & 2 & 6,2 & 3 & 9,4 & \\
\hline Besar Porsi Makana & & & & & & & & & & & & & \\
\hline Kurang Sesuai & 0 & 0 & 0 & 0 & 0 & 0 & 0 & 0 & 1 & 3,1 & 0 & 0 & \\
\hline Sesuai & 2 & 6,2 & 2 & 6,2 & 4 & 12,5 & 1 & 3,1 & 4 & 12,5 & 7 & 21,9 & 0,143 \\
\hline Sangat Sesuai & 1 & 3,1 & 1 & 3,1 & 0 & 0 & 5 & 15,6 & 2 & 6,2 & 2 & 6,2 & \\
\hline
\end{tabular}


sesuai sehingga menyebabkan makanan sudah dingin (Mas'ud et al., 2015).

Standar tingkat kematangan makanan masyarakat Indonesia adalah makanan harus dimasak dengan benar sehingga makanan tersebut layak untuk dimakan. Perhatian pada tingkat kematangan ini dapat dilihat pada Tabel 3. Pada menu makan siang mayoritas responden menyatakan lauk nabati di ruang rawat inap anak RUMKITAL Dr Ramelan memiliki tingkat kematangan sesuai. Sebanyak 18 orang (56\%) menyatakan tingkat kematangan sesuai atau lauk nabati telah matang sempurna untuk menu makan siang, namun hal tersebut tidak menunjukkan adanya hubungan yang signifikan antara tingkat kematangan lauk nabati pada makan siang dengan sisa makanan lauk nabati $\mathrm{p}=0,994(\mathrm{p}>0,05)$.

Hasil penilaian lebih dari separuh responden (63\%) terhadap tingkat kematangan lauk nabati pada makan malam menyatakan telah sesuai. Hasil uji statistik menunjukkan yang signifikan, yaitu $\mathrm{p}=0,049$, sehingga terdapat hubungan sisa makanan dengan tingkat kematangan lauk nabati pada makan malam. Adanya perbedaan kebiasaan makan dan kondisi fisiologis karena perbedaan jenis penyakit yang dialami pasien akan berpengaruh pada kemampuan menghabiskan makanan, apabila susunan menu, besar porsi, kebiasaan dan selera makan pasien tidak sesuai, maka diperlukan waktu untuk menyesuaikan (Wahyunani et al., 2007). Hal serupa juga dijelaskan Mas'ud et al. (2015) bahwa sisa makanan dapat terjadi akibat dari kondisi patologis dan klinis pasien, seperti gangguan menelan, nafsu makan, penurunan fungsi pengecapan, dan lama perawatan.

Asupan zat gizi yang menurun merupakan akibat dari kurangnya nafsu makan dan kebiasaan mengurangi makanan saat sakit, dehidrasi atau kehilangan cairan tubuh akibat sakit dan diare, mual serta muntah yang menyebabkan adanya peningkatan kebutuhan asupan akibat sakit, apabila kebutuhan tersebut tidak dipenuhi secara adekuat maka bakteri/parasit dapat terus berada dalam tubuh anak (Pahlevi, 2012). Asupan protein dalam tubuh anak berguna untuk membantu pertumbuhan dan pemeliharaan dengan menjaga zat-zat gizi dalam darah terkait fungsi kekebalan tubuh agar terhindar dari berbagai penyakit
(Murkherjee et al.,2008). Rendahnya selera makan pada anak merupakan penyebab kurangnya asupan makan sehingga penyakit mudah menyerang kekebalan tubuh anak (Pahlevi, 2012).

Adanya perbedaan daya terima yang terjadi pada penilaian makanan ini juga dipengaruhi faktor eksternal lain seperti penampilan makanan (warna, penyajian, besar porsi dan bentuk makanan) dan rasa makanan (aroma, bumbu, keempukan, tingkat kematangan dan suhu makanan) (Mutmainnah, 2008). Penerapan tingkat kematangan dapat digunakan untuk menggambarkan kematangan lauk nabati, apabila tidak sesuai tingkat kematangan suatu makanan, akan memengaruhi rasa makanan tersebut (Dewi dan Andriani, 2017).

Penilaian suhu makanan dilakukan pada saat makanan sampai ke tangan pasien dengan cara menanyakan secara langsung kepada orang tua pasien disertai dengan pengisian kuesioner. Hasil penelitian pada Tabel 3 menunjukkan bahwa separuh $(50 \%)$ pasien yang menyatakan suhu makanan lauk nabati yang disajikan pada makan siang sangat hangat. Hasil uji chi square menunjukkan tidak terdapat hubungan suhu makanan dengan sisa makanan lauk nabati pada waktu makan siang $(p=0,505)$. Sedangkan pada makan malam, uji statistik menunjukkan adanya hubungan bermakna antara suhu lauk nabati terhadap sisa makanan pada makan $(\mathrm{p}=0,040)$.

Pentingnya kesesuaian suhu makanan ini menentukan selera pasien dalam melahap makanan yang disajikan. Hal tersebut didukung oleh Kustiyoasih et al. (2016) yang mengatakan indikator cita rasa memiliki keakuratan dalam menilai kualitas produk makanan karena rasa dipengaruhi oleh beberapa faktor seperti temperatur dan tingkat sensitivitas rasa perorangan sehingga sangat berpengaruh bagi konsumen. Penelitian ini sejalan dengan penelitian Nuraini (2016) di RSUD Kota Semarang yang menjadi penyebab dari sisa makanan terbanyak pada makan malam yaitu makanan saat telah didistribusikan pada pukul 16.30-18.00 WIB pada pasien dan tidak langsung dikonsumsi, melainkan pasien baru akan mengonsumsi beberapa jam setelahnya. Makanan yang telah didistribusikan, baru dikonsumsi saat suhu makanan tersebut sudah tidak lagi sesuai, meskipun pada saat diterima suhu makanan telah 
sesuai. Hal ini memengaruhi nafsu makan dan selera makan pasien.

Pengulangan menu lauk nabati seperti olahan tempe/tahu dalam beberapa hari masa perawatan membuat pasien bosan dan enggan mengonsumsinya. Contoh menu yang ada di Rumkital Dr. Ramelan dalam tiga hari, antara lain, menu hari pertama pada siang perkedel tahu dan malam oseng tempe, sementara itu, menu hari kedua yaitu tempe bumbu kecap pada siang hari dan tahu bumbu santan pada malam hari, serta menu hari ketiga tahu bacem pada siang hari dan oseng tempe pada malam hari. Dapat dilihat bahwa adanya pengulangan menu tempe pada malam hari di menu hari pertama dan tempe di menu hari kedua pada siang hari merupakan jenis makanan yang menggunakan rasa dan bumbu yang serupa. Kondisi tersebut dapat menjadikan penyebab lain terjadinya sisa makanan waktu malam hari.

Beberapa jenis lauk nabati yang disajikan oleh Rumkital Dr. Ramelan setiap kali makan dinilai berdasarkan persepsi cita rasa masing-masing responden. Pada tabel 3 responden menilai bahwa lauk nabati yang dikonsumsi memiliki rasa yang enak di makan siang (53,1\% responden) dan rasa enak makan malam (46,9\% responden), namun sisa makanan lauk nabati masih tergolong banyak atau melebihi SPM Rumah Sakit. Hasil uji statistik menunjukkan tidak ada hubungan yang bermakna antara rasa lauk nabati dengan sisa makan siang $(\mathrm{p}=0,973)$ maupun sisa makan malam $(\mathrm{p}=0,577)$. Hal tersebut didukung penelitian Aula (2011) yang menyatakan bahwa tidak ada hubungan antara rasa makanan dengan sisa makanan yang terjadi di RS Haji Jakarta. Perbedaan persepsi rasa enak yang dikatakan oleh pasien bisa saja bergantung pada selera makan dan kondisi fisiologis masing-masing responden (Wahyunani et al., 2007).

Selera makan pasien juga didukung oleh adanya aroma dari suatu makanan agar kemauan untuk mengonsumsi makanan juga meningkat. Lauk nabati yang disajikan oleh Rumkital Dr. Ramelan dinilai telah sesuai atau harum oleh 17 responden $(53,1 \%)$ untuk makan siang dan 16 orang $(50 \%)$ untuk makan malam. Penilaian aroma lauk nabati tersebut tidak berhubungan dengan sisa makanan pada siang hari $(\mathrm{p}=0,994)$ dan malam hari $(\mathrm{p}=0,544)$. Hal tersebut sesuai dengan penelitian yang dilakukan oleh Muliani (2013) yang memperlihatkan $66 \%$ responden menyatakan aroma makanan sesuai. Indikator aroma ini terjadi akibat terbentuknya senyawa yang mudah menguap dan tercium oleh indra penciuman dan memberikan daya tarik yang kuat untuk membangkitkan selera makan (Wulansari et al., 2013). Penelitian ini juga menemukan bahwa tidak ada hubungan cita rasa (penampilan dan rasa makanan) dengan sisa makanan lauk nabati pada pasien anak, hal tersebut dijelaskan oleh Nuryati (2008) bahwa penampilan makanan dipengaruhi oleh penggunaan dan pemilihan alat makan yang sesuai dalam penyajian makanan ke pasien karena akan memengaruhi kemampuan pasien dalam menghabiskan makanannya.

Porsi yang diberikan lauk nabati di Rumkital Dr. Ramelan mengacu pada standar porsi yang telah ditentukan sebelumnya, dengan memperhatikan Ukuran Rumah Tangga (URT) dan standar diet. Penilaian besar porsi oleh responden terbilang cukup sesuai, karena mayoritas 19 responden $(59,4 \%)$ dan 20 responden $(63 \%)$ mengatakan porsi yang diberikan sesuai untuk lauk nabati anak di makan siang dan makan malam. Kesesuaian tersebut tidak signifikan dengan masih banyaknya sisa makanan yang dibuktikan dengan uji statistik pada sisa lauk nabati makan siang $(\mathrm{p}=0,503)$ dan sisa lauk nabati makan malam $(\mathrm{p}=0,143)$. Hasil penelitian ini sesuai dengan yang dilakukan Dewi dan Adriani (2017) di RS Islam Jemursari, yang menyatakan penyelenggaraan makanan menilai mayoritas puas dan sangat puas pada besar porsi yang disajikan oleh penyelenggara makanan swakelola dan hanya sebagian kecil yang menyampaikan porsi makanan terlalu sedikit. Pengaruh besar porsi berdampak pada penampilan yang nantinya akan mampu membuat persepsi tersendiri bagi pasien (Damayanti, 2014). Apabila porsi terlalu besar maka akan memengaruhi daya terima pasien. Ketidakpuasan terhadap besar porsi diakibatkan adanya ketidakseimbangan antara persepsi dengan harapan terhadap besar porsi yang disajikan (Kotler dan Keller, 2009).

Penilaian kesesuaian dalam penelitian mengenai tingkat kematangan dan suhu makanan ini menggunakan persepsi responden dan tidak menggunakan termometer makanan. 
Kondisi ini mengakibatkan terjadinya bias dalam mengategorikan sesuai dan tidak sesuai. Responden bisa memiliki kesamaan dan perbedaan dalam penentuan kesesuaian suhu dan tingkat kematangan. Sisa makanan pasien tergolong banyak meskipun suhu ataupun tingkat kematangan dinilai sesuai oleh pasien. Keterbatasan penelitian ini adalah tidak menggunakan alat pengukur suhu terstandar (termometer). Peneliti perlu melakukan validitas dan reliabilitas kuesioner yang diadaptasi dari penelitian sebelumnya untuk karakteristik pasien yang berbeda.

\section{KESIMPULAN DAN SARAN}

Dapat disimpulkan bahwa terdapat hubungan tingkat kematangan dan suhu dengan sisa makanan lauk nabati pada pasien anak RUMKITAL Dr. Ramelan di waktu makan malam Penelitian ini juga menunjukkan tidak ada hubungan pada variabel rasa, aroma dan besar porsi, dikarenakan adanya selera makan, kebiasaan makan dan kondisi fisiologis pasien. Daya terima pasien dapat dinilai dari sisa makanan yang disajikan RUMKITAL Dr. Ramelan dengan tetap mempertimbangkan faktor internal dan eksternal lainnya. Bagi instalasi gizi diharapkan melakukan evaluasi sisa makanan secara rutin dan menyeluruh agar mengetahui penyebab lain terjadinya sisa makanan pada pasien anak, sehingga nantinya mampu meningkatkan daya terima pasien terhadap makanan yang disajikan.

\section{PERSANTUNAN}

Terimakasih kepada seluruh pihak staff Sub Departemen Gizi RUMKITAL Dr. Ramelan atas masukan yang telah diberikan dan para pasien yang telah bersedia menjadi responden.

\section{DAFTAR PUSTAKA}

Atmanegara, Wa Ode., Djunaidi M.D., \& Yustini. (2013). Gambaran tingkat kepuasan siswa terhadap mutu hidangan pada penyelenggaraan makanan di sekolah polisi negara (SPN) Batua Polda Sulsel tahun 2013. Jurnal Universitas Hasanuddin: Makasar.
Ayudhia, D., et al. (2016). Asupan makanan, status gizi dan lama hari rawat inap pada pasien penyakit dalam di rumah sakit advent Manado. GIZIDO Vol. 8 No. 2 Nopember 2016: hal 22. Diakses dari www.ejurnal.poltekkesmanado. ac.id/index.php/gizido/article/view/337/368.

Aula, L.E. (2011). Faktor yang berhubungan dengan terjadinya sisa makanan pada pasien rawat inap di rumah sakit haji Jakarta. (Skripsi Sarjana Kesehatan Masyarakat, UIN Syarif Hidayatullah Jakarta). Diakses dari repository. uinjkt.ac.id.

Barker, A. Lisa., Gout, Belinda S., \& Crowe, C. Timothy. (2011). Hospital malnutrition: Prevalence, identification and impact on patients and the health care system.2011.Int. J. Environ. Res. Public Health 2011, 8(2), 514-527;doi:10.3390/ijerph8020514Diakses dari www.mdpi.com/journal.ijerph.

Damayanti, S. (2014). Hubungan variasi menu, besar porsi, sisa makanan, dan tingkat kepuasan pasien pada makanan lunak di rumah sakit umum daerah Cengkareng. (Skripsi Sarjana Gizi, Universitas Esa Unggul Jakarta), p. 5-7. Diakses dari digilib.esaunggul.ac.id/public/ UEU-Undergraduate-7953.

Depkes. (2007). Skrining malnutrisi pada anak yang dirawat di rumah sakit. Departemen Kesehatan Republik Indonesia.

Dewi, S.R. \& Adriani, M. (2017) perbedaan kepuasaan pasien terhadap makanan dengan sistem penyelenggaraan outsourcing dan swakelola di RS Islam Jemursari Surabaya. Amerta Nutr 209-219. DOI : 10.2473/amnt. v1i3.2017.209-219. Diakses dari : e-journal. unair.ac.id/AMNT/article/view/6247/3863.

Koen F.M. \& Jessie M.H. (2008). Prevalence of malnutrition in pediatric hospital patients. Current Opinion in Pediatrics. 20(5), p. 590-596, Diakses dari http://journals.lww.com/ co-pediatrics.

Kotler, P., \& Keller, K. (2009). Marketing Management (13th ed). New Jersey: Prentice Hall International, Inc. p. 32-33.

Kustiyoasih, M.P., Andriani, M., \& Nindya, T.S. (2016). Penyelenggaraan makanan dan kepuasan konsumen di kantin lantai 2 Rumah Sakit Universitas Airlangga Surabaya. Media Gizi Indonesia, Vol. 11, No. 1 Januari-Juni 2016: hal. 11-16. Diakses dari: e-journal.unair. ac.id/MGI/. 
Lieke, O. (2013). Status gizi dan penyelenggaraan makanan diet pasien rawat inap di BLU Prof. Dr. R.D. Kandou Manado. Jurnal Gizido, 5(2), 11-19 .Diakses dari http://ejurnal. poltekkesmanado.ac.id/index.php/gizido/ article/download/289/304.

Mas'ud, H., Rochimiwati., \& Rowa. (2015). Studi evaluasi sisa makanan pasien dan biaya makanan pasien di RSK Dr Tadjuddin Chalid dan RSUD kota Makasar. Media Gizi Pangan, Vol. XIX, Edisi 1 2015: hal. 91-95. Diakses dari http://mediagizipangan.org/wp-content/ uploads/2016/08/15.-jurnal-sisa-makananpasien-.pdf.

Mukherjee., Maj, R., Chaturvedi, L.S.C., \& Bhalwar, C.R. (2008). Determinants of nutritional status of school children. MJAFI, 64(3) p. 227-23.

Mutmainnah. (2008). Daya terima makanan dan tingkat konsumsi energi-protein pasien rawat inap penderita penyakit dalam di rumah sakit Dr. H. Morzoeki Mahdi. (Skripsi Sarjana Gizi, Institur Pertanian Bogor). Diakses dari repository.ipb.ac.id.

Nuraini, N. (2016). Suhu makanan dan sisa makanan pasien dewasa diet lunak di ruang rawat inap penyakit dalam rumah sakit umum daerah kota Semarang. Jurnal Gizi Unimus p. 41-48. Diakses dari jurnal.unimus.ac.id.

Nuryati, P. (2008). Hubungan antara waktu penyajian, penampilan, dan rasa makanan dengan sisa makanan pada pasien rawat inap dewasa di rumah sakit Bhakti Wira Tamtama Semarang. Jurnal Gizi Unimus, 36(2), p. 13-26.

Pahlevi, A.E. (2012). Determinan status gizi pada siswa sekolah dasar. Jurnal Kesehatan Masyarakat, 7 (2), p. 122-126.

Prawirohartono. (2009). Peningkatan daya terima makanan di rumah sakit.Gizi Indonesia. Edisi $\mathrm{X}$.

Muliani, U. (2013). Faktor-faktor yang berhubungan dengan sisa makanan saring pasien rawat inap. Jurnal Keperawatan, Vol. IX, No. 1, hlm. 31-36.

Wahyunani, B.D., \& Susilo, W. (2017). Hubungan tingkat kepuasan pasien terdapat pelayanan gizi dengan sisa makanan pasien vip di rumah sakit panti rapih Yogyakarta. Jurnal Nutrisia, Vol. 19 No. 2, September 2017, hal. 119-125.

Widyastuti, N. \& Pramono, A. (2014). Manajemen jasa boga. Yogyakarta: Graha Ilmu.

Wulansari, A., Setiawan, B., \& Sinaga, T. (2013). Penyelenggaraan makanan dan tingkat kepuasan konsumen di kantin zea mays institut pertanian Bogor. Jurnal Gizi dan Pangan Vol. 8 : Hlm. 151-158. Diakses dari http:// jurnal.ipb.ac.id/index.php/jgizipangan/article/ download/7693/595. 